\title{
PROPAEDEUTIC OF PROGRAMMING AND NEW SCHOOL REFORM
}

\section{Veronika STOFFOVÁ - Krisztina CZAKÓOVÁ}

\begin{abstract}
Programming as a subject of teaching at elementary and secondary schools in Slovakia went a long way. The new school reform has reintroduced programming into the subject content of Informatics for both primary, and secondary schools in the State educational program. But at the schools, there are not enough qualified teachers to teach programming. The article describes a way how to solve this problem and also deals with response of some universities to need of augmentation of information and programmer literacy of future teachers and teachers in practice.
\end{abstract}

Key words: informatics, programming, teaching of programming, programmer literacy.

\section{PROPEDEUTIKA PROGRAMOVANIA A NOVÁ ŠKOLSKÁ REFORMA}

Resume: Programovanie ako predmet vyučovania na základných a stredných školách prešlo na Slovensku dlhým vývojom. Nová školská reforma ho znovu zaradila do obsahu predmetu Informatika v Štátnom vzdelávacom programe tak na základných, ako aj na stredných školách. Na školách ale ešte stále nie je dostatok kvalifikovaných učitel'ov na vyučovanie programovania. Článok opisuje spôsob riešenia tohto problému a zaoberá sa tiež tým ako reagujú niektoré univerzity na potrebu zvýšenia informačnej a programátorskej gramotnosti budúcich učitel'ov a učitel'ov z praxe.

Kl'účové slová: informatika, programovanie, vyučovanie programovania, programátorká gramotnost'.

1 Programovanie vo všeobecnom vzdelávaní v (Česko-)

SlovenskuV začiatkoch informatizácie školstva, vlastne v období elektronizácie školstva, ked' panovali v tejto oblasti na stredných a vysokých školách školské výpočtové strediská, tvorilo programovanie hlavnú nápln̆ predmetu, ktorý niesol názov Výpočtová technika, príp. Programovanie. Príchodom osobných počítačov (s osembitovým procesorom) sa obsah predmetu podstatne nezmenil. Názorový boj sa viedol len o preferenciu používaného programovacieho jazyka. Diskutovalo sa či použit' interpretovaný jazyk BASIC (teda programovací jazyk bez prekladača), alebo či na zvládnutie základov programovania používat' jazyk Pascal s prekladačom. V tom čase sa v rámci algoritmizácie a programovania riešili rôzne numerické problémy, najmä rôzne výpočtové postupy a procesy. S vývojom počítačov, so vznikom terminálových a počítačových sietí, s rozmachom Internetu a multimédií koncom 20. storočia sa využitie počítačov zmenilo. Vyučovanie programovania sa dostalo do úzadia, prevládol používatel'ský prístup a počítač sa stal univerzálnym didatickým prostriedkom. Čas ukázal, že efektívne a inteligentné využívanie možností počítačov ich bohatého hardvérového a softvérového vybavenia je podmienené algoritmickým a programátorským myslením. Toto poznanie vyvolalo aj zmenu koncepcie vyučovania informatiky. V súčasnosti je však programovanie znova neoddelitel'nou súčast'ou predmetu Informatika na všetkých typoch škôl.

\section{Programovanie $\quad v \quad$ primárnom a sekundárnom vzdelávaní na Slovensku podl'a novej školskej reformy}

Príprava žiakov na základných a stredných školách na Slovensku sa riadi Štátnym vzdelávacím program, ktorý je záväzným dokumentom. Stanovuje všeobecné ciele vzdelávania a klúčové kompetencie, ku ktorým má vzdelávanie smerovat'. Ciele vzdelávania sú postavené tak, aby sa zabezpečil vyvážený rozvoj osobnosti žiakov. Štátny vzdelávací program vymedzuje aj rámcový obsah vzdelávania. Je východiskom pre tvorbu školského vzdelávacieho programu, v ktorom sa zohl'adňujú aj špecifické podmienky a potreby regiónu. Štátny vzdelávací program vydáva a zverejňuje pre jednotlivé stupne vzdelania Ministerstvo školstva, vedy, výskumu a športu Slovenskej republiky (1). Štátny vzdelávací program (ŠVP) sa skladá z niekol'kých relatívne samostatných častí podl'a stupňa a zamerania vzdelávania: ŠVP pre materské školy (ISCED 0); ŠVP pre 1. stupeň základných škôl (ISCED 1); ŠVP pre 2. stupeň základných škôl (ISCED 2); ŠVP pre gymnáziá 
(ISCED 3A); ŠVP pre základné umelecké školy (ISCED 1B, 2B); ŠVP pre konzervatóriá (ISCED 5); ŠVP pre jazykové školy (SERR); Vzdelávací program (VP) pre deti a žiakov so zdravotným znevýhodnením;VP pre žiakov so všeobecným intelektovým nadaním.

Všeobecným obsahom jednotlivých dokumentov (modulov) sú: Ciele vzdelávania; Stupeň vzdelávania; Profil absolventa; Vzdelávacie oblasti; Charakteristika vzdelávacích oblastí; Prierezové témy; Vzdelávacie štandardy; Rámcové učebné plány; Organizačné podmienky na výchovu a vzdelávanie; Povinné personálne zabezpečenie; Povinné materiálno-technické a priestorové zabezpečenie; Podmienky bezpečnosti a ochrany zdravia; Osobitosti a podmienky na výchovu a vzdelávanie žiakov so špeciálnymi výchovno-vzdelávacími potrebami; Výchova a vzdelávanie žiakov so zdravotným postihnutím; Výchova a vzdelávanie žiakov zo sociálne znevýhodneného prostredia; Výchova a vzdelávanie žiakov s nadaním a Zásady a podmienky pre vypracovanie školských vzdelávacích programov.

\section{Nová školská reforma $v$ oblasti informatiky a programovania}

Nová školská reforma prebieha od 1 . septembra 2008. Školy v školskom roku 2008/2009 začali učit' podl'a vlastných školských vzdelávacích plánov $\mathrm{v}$ prvom a piatom ročníku základnej školy a v prvom ročníku strednej školy. Výnimku tvorili žiaci vyšších ročníkov, ktorí pokračovali podl'a pôvodných učebných plánov. V aktuálnom školskom roku 2011/2012 sa podl'a nových vzdelávacích plánov učia takmer všetci žiaci (okrem žiakov deviateho ročníka) základných škôl a všetci žiaci stredných škôl.

Jednou $\mathrm{z}$ hlavných zmien podl'a novej školskej reformy $v$ oblasti informatiky je zmena hodinovej dotácie na základných a stredných školách. V tabul'ke 1 je uvedený rozsah vyučovania, podl'a štátneho vzdelávacieho programu pre 2. stupeň základných škôl a pre nižšie vyššie sekundárne vzdelávanie. Tieto hodinové dotácie si každá škola môže upravit' v rámci svojich školských vzdelávacích plánov (ale len smerom nahor) $(1,2,3,4)$.

Hodinové dotácie a úspešná realizácia výučovania predpokladajú dostatočný počet kvalifikovaných učitel'ov informatiky na všetkých typoch škôl. Kvalifikačné zloženie učitel'ov v čase štartovania školskej reformy bolo ale nevyhovujúce. Nedostatočnú kvalifikovanost' učitel'ov informatiky potvrdzovali mnohí zainteresovaní odborníci a výsledky prieskumov, ktoré boli $\mathrm{v}$ tom čase vykonané. I napriek mnohým iniciatívam, zmenám a projektom, (ktoré boli začaté, príp. v súčasnosti už niektoré aj ukončené), štatistiky ukazujú, že na základných a stredných školách je ešte stále málo kvalifikovaných učitel’ov informatiky, s čím úzko súvisí aj nedostatočné naplnenie očakávaní novej školskej reformy.

Tabul'ka 1 Rozsah vyučovania informatiky na ZŠ a na gymnáziách

\begin{tabular}{|l|r|r|r|r|r|r|r|l|}
\hline Základná škola & & & & & & & & \\
\hline Ročník & 5 & 6 & 7 & 8 & 9 & & & \\
\hline Počet hodín & 0,5 & 0,5 & 0,5 & 0,5 & 0,5 & & & \\
\hline Štvorročné gymnázium & & & & & & & & \\
\hline Ročník & 1 & 2 & 3 & 4 & & & & \\
\hline Počet hodín & 1 & 1 & 1 & 0 & & & & \\
\hline Osemročné gymnázium & & & & & & & & \\
\hline Ročník & 1 & 2 & 3 & 4 & 5 & 6 & 7 & 8 \\
\hline Počet hodín & 0,5 & 0,5 & 0,5 & 0,5 & 1 & 1 & 1 & 0 \\
\hline
\end{tabular}

Zo skúseností učitel'ov informatiky na základných školách vieme že, pokial’ si škola nerozšíri počet hodín predmetu Informatika $\mathrm{v}$ rámci svojho školského vzdelávacieho plánu, je 
počet hodín vyhradených pre informatiku nedostatočný. Učitelia nemajú priestor dostatočne sa venovat' jednotlivým témam tak, ako by to bolo potrebné. Jedna hodina raz za dva týždne zároveň znamená, že žiaci sa málo dostávajú do kontaktu sučitel'om a plánovaným učivom a majú malý priestor na precvičenie svojich znalostí a získanie potrebných zručností. Preto je na mieste pouvažovat' nad efektivitou vyučovania a možnost'ou presunút' nacvičovanie zručností do domácej prípravy, príp. do organizovaného mimovyučovacieho času.

Obsah predmetu Informatika a zaradenie tematického celku Programovanie na ZŠ a na gymnáziach v Slovenskej republike vymedzujú záväzné dokumenty, ktoré stanovujú vzdelávací štandard pre predmet Informatika. Sú to:

Štátny vzdelávací program pre 1. stupeň základných škôl (ISCED 1) - ktorý tvoria 1. až 4. ročník (2)

Štátny vzdelávací program pre 2. stupeň základných škôl (ISCED 2), ktorý tvoria 5. až 9. ročník primárneho vzdelávania (3).

Štátny vzdelávací program pre gymnáziá (ISCED3A - podla ktorého sa vzdelávajú žiaci gymnázií so štvorročným štúdiom a žiaci 5 . až 8 . ročníka gymnázií s osemročným štúdiom (4).

Štátne vzdelávacie programy stanovujú povinné vyučovacie predmety, ktoré sú začlenené do jednotlivých vzdelávacích oblastí. $\mathrm{V}$ rámci svojho školského vzdelávacieho programu si každá škola môže vytvorit' aj vlastný vyučovací predmet (využitím vol'ných disponibilných hodín). Okrem vyučovaných predmetov sú zavedené aj prierezové témy, ktoré sa prelínajú všetkými vzdelávacími oblast’ami.

Všetky ŠVP, ktoré boli explicitne citované vyššie, boli schválené na gremiálnej porade ministra školstva dňa 19.6.2008.

Štátne vzdelávacie programy predstavujú dôležité dokumenty aj v usmerňovaní vyučovania programovania. V ŚVP ale nie je uvedené $\mathrm{v}$ akom programovacom prostredí má žiak získavat' svoje programátorské vedomosti a zručnosti. Dokonca nie je uvedené ani to, či sa majú žiaci učit' $\mathrm{v}$ prostredí detského programovacieho jazyka alebo v niektorých programovacích jazykoch vyššej úrovne, či už procedurálnych alebo objektovo orientovaných, alebo či radšej použit' niektoré programovacie prostredie. To je správne, lebo učitel' sa môže rozhodnút' podl'a vlastného uváženia. Správne rozhodnutie ale predpokladá dostatočnú programátorskú gramotnost', pedagogickú a didaktickú erudovanost' učitel'a. Fakt, že ŠVP nenariad'uje v akom prostredí pracovat', možno potvrdzuje aj to, že nie je tak dôležité prostredie a prostriedky, ktoré používame, ale spôsob ako ich využívame.

Z množiny detských programovacích jazykov sú na slovenských školách rozšírené: SGP Baltik, Baltazár, LOGO, Comenius Logo, Imagine Logo, (Žofka); Karel, Karel 3D a pod. Základné vlasnosti detských programovacích jazykov sú:

- umožňujú pomocou zabudovaných príkazov niekoho (alebo niečo) ovládat';

- obsahujú niekol'ko základných príkazov, ktoré je možné spájat' do zložitejších celkov;

- sú určené na prvé zoznámenie sa s programovaním $(5,6)$.

Z oblasti mikrosvetov sú známe: Ferdo Mravec, Králiček Petr, Robot Karel, Cabri Geometria atd'. Mikrosvety sú otvorené programové prostredia. Sú vhodné pre problémové vyučovanie a sú určené na experimentovanie v konkrétnej oblasti. Mikrosvetom môže byt' napr. aplikácia naprogramovaná $\mathrm{v}$ Logu. Diet'a $\mathrm{v}$ ňom rieši rôzne úlohy a tým objavuje zákonitosti, ktoré $\mathrm{v}$ ňom platia, umožn̆uje vytvárat' vlastné mikrosvety, ktoré diet'at'u slúžia na modelovanie zjednodušeného reálneho sveta (typickým príkladom mikrosveta pre diet'a je napr. rodina, škola, svet kamarátov, život na vidieku u starých rodičov atd'.).

Základnými vlastnost’ami mikrosvetov sú: interaktívnost', vizualizácia a otvorenost'.

Významnú úlohu v osvojovaní základov programovania môžu zohrat' programovatel'né hračky a stavebnice: včela Bee-Bot, Lego Dacta, počítačové lego RCX, RoboLab, stavebnice LEGO WeDo a LEGO Mindstorms NXT (s programovacími jazykmi NXT-G, NBC, NXC, RobotC, LeJoS) atd'.

Absolventi odboru učitel'stva akademických predmetov informatika $\mathrm{v}$ kombinácii $\mathrm{s}$ iným predmetom sú obyčajne dostatočne pripravení a väčšinou sa prispôsobia aktuálnemu stavu výučby na škole, na ktorú nastúpia. Vyučovanie programovania realizujú so žiakmi v prostredí, ktoré si zvolí predmetová komisia konkrétnej výchovno-vzdelávacej inštitúcie, alebo v prostredí, ktoré si zvolia sami $(7,8,9,10)$.

Z našich osobných skúseností ako aj zo skúsenosti iných kolegov a pedagógov s ktorými sme sa stretli a konzultovali túto otázku, sme zistili, že na druhom stupni základných škôl prevládajú detské programovacie jazyky ako sú Imagine, Comenius Logo, a na niektorých aj 
detský programovací jazyk Baltík (5). Hlavné dôvody sú, že učebnica pre základné školy je vytvorená pre prostredie detského programovacieho jazyka a na Slovensku existuje viacero programátorských sút’aží pre základné školy, ktoré sú realizované v prostredí detských programovacích jazykov.

Na štvorročných gymnáziách sú vyučované najmä programovacie jazyky Pascal, Delphi a Lazarus. Na stredných odborných školách sú vyučované skôr jazyky a prostredia určené na tvorbu webových stránok a na rýchlu tvorbu aplikácií, z programovacích jazykov sa vyučujú objektovo orientované jazyky C, C++ alebo C\#.

\section{Ako možno tvorbou aplikácie v prostredí Imagine a LogoMotion naučit' základy programovania}

Za účinný a osvedčený spôsob vyučovania programovania považujeme tvorbu aplikácie $\mathrm{v}$ danom programovacom jazyku, príp. programátorskom prostredí, kombináciou problémového a projektového vyučovania. Žiaci postupne zvládnu predpísané prvky programovania a využívanie rôznych elementov prostredia a ich možnosti pri riešení jednoduchých čiastkových problémov.

\section{Postup:}

1. Žiaci sa zoznámia s hotovými aplikáciami, ktoré sú dokončené a funkčné a obsahujú rôzne čiastkové riešenia, ktoré môžu byt' užitočné a využitel'né aj v novej aplikácii (Tieto aplikácie slúžia u žiakov ako motivácia a zároveň aj na získanie dôvery vo vlastné schopnosti. Obyčajne ukazujeme výsledky projekty žiakov z predchádzajúcich ročníkov, to ich presvedčí o tom, že naše požiadavky nie sú nad ich možnosti a schopnosti.);

2. Sústredíme sa na rôzne programátorské konštrukcie, ukážeme ako fungujú (ako hotové riešenia a čiastkové riešenia nových problémov)

2 a) ukážeme príklady sekvencií,

2 b) ukážeme príklady vetvení a ich zápisu,

2 c) ukážeme príklady opakovaní a ich zápisu (Žiaci sa snažia jednotlivé príklady pochopit'.)

3. Hladáme uplatnenie jednotlivých riadiacich konštrukcií v riešení nového projektu; (Úlohou žiakov je objavit', kde môžu uplatnit' hotové čiastkové riešenia vo vlastných projektoch.);

4. Na funkčnej aplikácii ukážeme použivanie rôznych prvkov prostredia a hladáme ich uplatnenie pri riešení analogických problémov v novom projekte;
5. Žiakom predstavíme d'alšie možnosti prostredia (prostriedku) a hl'adáme možnost' ich použitia v projekte na rozšírenie jeho funkčnosti a možností a na zvýšenie jeho kvality, interaktivity, jednoduchého používania a pod.

Žial' obmedzený rozsah článku neumožňuje podrobný opis a analýzu postupu ako vyučujeme programovanie tvorbou aplikácií v prostredí Imagine a LogoMotion. Stručne možno povedat', že používame metódu, ku ktorej sme sa dopracovali dlhodobým vyučovaním programovania $\mathrm{v}$ rôznych programovacích jazykoch a programátorských prostrediach. Osvedčila sa ako univerzálna metóda tak na vyučovanie programovania, ako aj na vyučovanie tvorby programových aplikácií. Nazvali sme ju špirálovitá. Po zvládnutí základov postupne pribal'ujeme d’alšie prvky a možnosti, kým edukant nezíska ucelený obraz o programovaní a o samotnom prostredí, aby $\mathrm{v}$ ňom dokázal optimálnym spôsobom vytvárat' aplikácie a využivaním jeho možností vhodným spôsobom sa pri tom naučil programátorsky mysliet'.

\section{Záver}

Univerzity, ktoré priravujú učitel'ov, reagovali na požiadavky praxe na základe nového školského vzdelávacieho programu rôzne. V rámci projektu Štátneho pedagogického ústavu Dištančné vzdelávanie učitel'ov informatiky (DiVUi) realizovali (príp. niektoré kurzy ešte stále bežia) rôzne preškol'ovacie kurzy a to tak pre učitel'ov informatiky, ako aj pre učitel'ov neinformatikov. $\mathrm{Na}$ realizáciu kurzov boli vybraté len niektoré vysokoškolské vzdelávacie inštitúcie a ich určení pracovníci. V prvej fáze prebehla príprava lektorov a obsahu kurzov pre učitel'ov a potom ich realizácia. Priebežne sa pripravovali aj učebnice, pracovné zošity a učebné pomôcky, tak pre tieto kurzy, ako aj pre školy.

Školská reforma sa mala odrazit' aj na študijných programoch učitel'ského štúdia, aby z univerzít vychádzali absolventi dobre pripravení plnit' očakávania ŠVP, a aby nemuseli absolvovat' hned' po skončení vysokoškolskej prípravy nejaký preškol'ovací kurz pred nástupom do praxe navyše. Mnohé univerzity v rámci volitel'ných predmetov $\mathrm{C}$ kategórie zaviedli rôzne predmety ako napr. programovanie, tvorbu aplikácií, mikrosvety, detské programovacie jazyky, robotiku, programovanie robotov a pod. Tak rozšírili možnosti výberu predmetov nielen pre budúcich učitel'ov informatiky, ale hlavne pre budúcich 
učitel'ov, ktorí neštudujú informatiku ako svoj aprobačný predmet.

Možno skonštatovat', že absolventi učitel'stva informatiky prichádzajú do praxe dostatočne pripravení a bez problémov zvládajú aj obsah vyučovania programovania aj jeho patričnú pedagogickú transformáciu. Nie je ale jednoduché dat' jednoznačnú odpoved' na otázku ako programovanie efektívne a správne učit', aké prostriedky a prostredia využívat' na získanie zručnosti tak, aby si osvojili filozofiu programovania, získali a rozvíjali svoje algoritmické a programátorské myslenie, aby ich to bavilo (11-14). Aby pri zmene programovacieho prostriedku, príp. prostredia, sa rýchlo zadaptovali a nerobilo im problémy podat' dobrý programátorský výkon. Preto nie je tak dôlžité prostredie a prostriedok, ktorý používame, ale spôsob ich využívania. Kým určitý prostriedok v rukách jedného učitel'a je silným didaktickým prostriedkom, ktorý motivuje a aktivizuje žiakov do tvorivej činnosti, v prípade druhého, nesprávnym používaním toho istého nástroja, pri chýbajúcej pedagogickej erudícii, nedostatočnom pedagogickom majstrovstve a cite, pri precenení, príp. podcenení môžností žiakov, môže edukantov demotivovat' až odradit' od programovania.

\section{Zoznam bibliografických odkazov}

[1] Štátny vzdelávací program [on-line]. Bratislava: Štátny pedagogický ústav, 2008. [cit. 2012-05-04]. Dostupné na: http://www.statpedu.sk/sk/Statny-vzdelavaciprogram.alej

[2] Štátny vzdelávací program pre 1. stupeň základných škôl (ISCED 1) [on-line]. Bratislava: Štátny pedagogický ústav, 2008. [cit. 2012-0504]. Dostupné na: ŠVP pre 1. stupeň základných škôl (ISCED 1)

[3] Štátny vzdelávaci program pre 2. stupeň základných škôl (ISCED 2) [on-line]. Bratislava: Štátny pedagogický ústav, 2008. [cit. 2012-0504]. Dostupné na: ŠVP pre 2. stupeň základných škol (ISCED 2)
[4] Štátny vzdelávací program pre gymnáziá (ISCED3A) [on-line]. Bratislava: Štátny pedagogický ústav, 2008. [cit. 2012-05-04]. Dostupné na: ŠVP pre gymnáziá (ISCED 3A)

[5] GABALOVÁ, V. Mikrosvet - vhodný prostriedok na vyučovanie základov programovania In: Huraj (eds.) DidInfo 2002. Banská Bystrica: FPV Univerzity Mateja Bela, 2008, s. 39 (abstrakt), príspevky na CD. ISBN 978-80-8083-367.

[6] GABALOVÁ, V. Názor študentov učitel'stva na zaradenie počítačov do predškolského vzdelávania. In: XIX. DIDMATTECH 2006. 1. vyd. Komárno: Univerzita J. Selyeho, 2007, s. 278-280. ISBN 978-80-89234-23-3.

[7] CHRÁSKA, M. jun. Informační výchova, informační technologie. In: PROCHÁZKOVÁ, I.

et al.: Technická výchova součást humanistického modelu pregraduální prípravy učitelü. 1. vyd. Olomouc: Votobia Praha, 2005, s. 69-98. ISBN 80-7220-213-8.

[8] CHRÁSKA, M. Měnící se role učitele a žáka v nastupující informační společnosti výsledky výzkumu. In: XX. DIDMATTECH : Díl II. Editori Ján Stoffa, Veronika Stoffová a Miroslav Chráska jun. 1. vyd. Olomouc: Votobia Olomouc, 2007, s. 458-463. ISBN 807220-296-0.

[9] STOFFOVÁ, V. - KIS-TÓTH, L. A tanárjelöltek új információs technologiára való felkészülese Szlovákiabán és Magyarországon. In: Agriamedia '98. Eger: EKTF, 1998, s. 75-81.

[10] SERAFÍN, Č. Budoucnost technologií ve vzdělání. In: Sborník př́spevků: XX. Mezinárodní kolokvium orrizení osvojovacího procesu. Vyškov: Vysoká vojenská škola pozemního vojska. 2002. s. 362-364. ISBN: 80-7231-090-9

[11] PIĄTEK, T. Humanistyczno - etyczne aspekty stosowania technologii informacyjnych. In: XX. DIDMATTECH : Díl II. Editori Ján Stoffa, Veronika Stoffová a Miroslav Chráska jun. 1. vyd. Olomouc: Votobia Olomouc, 2007, s. 547-549. ISBN 80-7220-296-0. 
[12] STOFFOVÁ, V. Počitač, univerzálny didaktický prostriedok. FPV UKF Nitra: Edícia prírodovedec č.152, Nitra, 2004. 172 s., ISBN 80-8050-765-1.

[13] VÉGH, L. Vizualizácia algoritmov vo vyučovaní programovania. In: Informatika $v$ škole a v praxi. Ružomberok: Pedagogická fakulta Katolíckej univerzity v Ružomberku, 2006, s. 65-69. ISBN 80-8084-112-8.

[14] WALAT, W. Edukacyjne zastosowania hipermediów. 1. vyd. Rzeszów: Wydawnictwo Uniwersytetu Rzeszowskiego, 2007. 320 s. ISBN 978-83-7338-329-6.
Posudzovatel': Prof. Dr. Ing. Imrich Okenka, $\mathrm{PhD}$.

Veronika Stoffová, Prof., Ing., CSc.

Univerzita J. Selyeho, Komárno

e-mail: NikaStoffova@seznam.cz

Krisztina Czakóová, PaedDr.,

Univerzita J. Selyeho, Komárno

e-mail: tothk@selyeuni.sk 